\title{
Charcot-Marie-Tooth disease type 4D
}

INSERM

\section{Source}

INSERM. (1999). Orphanet: an online rare disease and orphan drug data base. CharcotMarie-Tooth disease type 4D. ORPHA:99950

Charcot-Marie-Tooth disease type 4D (CMT4D) is a subtype of Charcot-Marie-Tooth disease type 4 characterized by a childhood-onset of severe, progressive, demyelinating sensorimotor neuropathy manifesting with distal muscle weakness and atrophy, sensorineural hearing impairment leading to deafness (usually in third decade), severely reduced nerve conduction velocities, and skeletal, especially foot, deformities. Tongue atrophy has also been reported. 